\title{
5 Arab Customs and Beliefs
}

\subsection{Arab Death}

If the deadly cold weather fatally freezes the Muslim woman in her tulle or calico dress, it is not because her race ignores the art of preserving life: ousted from their land by our administration, despoiled, overcome by privations and dying of hunger in the countryside, or haggard, emaciated, and dying in the city, Arabs possess more than other people in the world the ability to delay the time of death. First, they are sober like their camels, they practice hygiene ${ }^{89}$ according to their religion; then, they have remedies for all diseases.

The Arab, essentially an observer, is considered dirty by ignorant Europeans when he prefers cloudy and healthy water to the clear and fresh water that causes colic and fever. What way of easing pain or healing do we have that native Algerians do not? It is from them we have learned to apply fire to the diseased part of our body. Well before Pasteur's inoculation against rabies and before Jenner's vaccination, they vaccinated themselves against small pox to lessen its effects. To do this they make an incision between the thumb and index finger and put in it the pus of a small pox sufferer. But they do not want this pus to come from a cow or a Jew, not wanting, they say, to "cow or jew themselves down.” This explains their resistance to official vaccination.

When they are ill, Muslims not only cover themselves with amulets, they also take multiple Moorish baths. "The bath is a silent doctor," says an Arab proverb. The Saharan who suffers from colic or fever believes he will heal if he tightly squeezes his big toe with a silk thread; he does not neglect, however, to wrap his belly in sheep's skin. The sick inhabitant of the Tell is not content to get his health back by eating on a foreigner's grave, he also uses medicinal herbs; his toubibs (doctors) have taught him the virtue of the plants he tramples underfoot. He knows when to use the bou-afia (father of good health) which gave us the thapsia, mustards, sarsaparilla, bittersweet, soapberry, the big mallows, terebinth, anise, fennel, chamomile, pyrethrum, ricin, saffron, sage, lavender, mint, verbena... But his medication of choice is the onion! Should he have a stomachache, he eats onion; should he have colic, he wraps his belly in a cataplasm of cooked onions.

If this panacea protects him for a long time, it does not prevent him from getting to our common end, death. He is actually resigned to it and often repeats this proverb:

It is better to be sitting than standing;

It is better to be lying down than sitting;

It is better to be dead than alive.

89 According to Dr. Grenier, the science found in the Koran about hygienic prescriptions goes further than the base of knowledge acquired by humanity before Mohammed. (author's footnote)

(cc))BY-NC-ND $(C) 2014$ Hubertine Auclert

This work is licensed under the Creative Commons Attribution-NonCommercial-NoDerivs 3.0 License. 
His fatalism makes him bear pain heroically. When an adored son or a favorite dies, he stoically exclaims Mektoub! (it was written). Not only is the Arab resigned to death, but he is often so tired and desperate, that he wishes for it when he falls on the side of the road, where wild animals devour him sometimes before he is a corpse.

Like the Greeks, the Gauls, the Romans, and the Germans who wanted their dear departed to enter the paradise of their dreams dressed up and attractive to the eyes, the Muslims lay out the body of their dead.

As soon as somebody dies, the corpse is carefully washed and perfumed. Herbs, camphor, and cotton are put in each natural cavity. If the dead has been guillotined, the head is carefully sewn back to the torso so that Allah will have no difficulty in recognizing him. If the deceased is a woman, her hair is carefully combed, divided by a part in the middle of her head, and gracefully let down on her chest; then her body is wrapped in five white sheets. A man's body is wrapped in only three pieces of cloth.

Mohammed was a hygienist and did not want the dead to pass through the mosque, compromising the health of the living; so they are taken straight from their dwelling to the cemetery, like free-thinkers. Surprised foreigners stop when in the streets of Algeria's towns or villages they meet large crowds, including Aïssaouas with their unfurled flags, or a small group of silent Arabs holding on their finger tips, according to the custom, a long shapeless package covered with a moire cloak trimmed with gold, which they pass on from fingers to fingers. It is a dead person brought to his or her final resting place, without speech or flowers, and without a coffin. The corpse will lie in the bare earth; so Arabs want to protect it from the teeth of jackals and hyenas that plague certain regions. As soon as it is buried at a depth of thirty to forty centimeters, they construct a little piece of masonry around the grave and also place on it rough stones covered with epitaphs. This does not prevent many fenceless Arab cemeteries, like those I have seen, from being visited at night by wild animals which, smelling the corpses and being unable to unearth them, scare the living with their roars and roam around the houses for hours when leaving the cemeteries.

M'zabite funerals take place at night and in the utmost secrecy; they must not be seen by strangers to their religion. The Kabyles dig the pit before the death of the sick person, who is buried as soon as breathing stops, with the result that someone who has fainted can be taken for dead. When these unfortunate people awaken in their pit and moan and bang, it is said that they are being hit with a "truncheon" as punishment for their sins, and instead of opening the grave, the living kneel on it and pray. Our inhuman administration is indifferent to the torture of those buried alive.

In the past, when the king of the Congo died, his body was kept for several months and then brought in a straight line to the grave, with everything destroyed in its passage. The kings of the Roua are buried with living women in a river bed. The Dahomean chiefs are buried exactly where they expired. The Pahouin widows are buried naked and painted green. Numerous African peoples bury their dead chiefs with several living virgins. The body of the Hova sovereign is enclosed 
in a silver canoe. The Zabarat, Arab tribes of the Sudan, who adore the purifying fire and the invigorating sun, bury their dead with the head turned toward the rising sun, then they light a pyre on the grave to carry away the deceased's soul in a whirl of flames and light. The simoon, ${ }^{90}$ which buries caravans in the desert, has taught most inhabitants of Africa to have burials. They often leave food near the dead.

Great Arab men, saints, marabouts, as well as heroines and prophetesses, are buried in a koubba in a mosque. It is their Pantheon. Before entering these white koubbas that dot the Algerian landscape with their square cupolas, these individuals have gone through an embalming that has mummified them. They rest in the funerary room on a kind of big bed, or catafalque, adorned with piles of old multicolored silk finery, green flags with golden crescents, necklaces, rosaries, ostrich eggs... As I mentioned before, there are also women's tombs in the koubba, such as that of Lalla Khedidja on the mountain of the same name, the snowy crest which is visible from Algiers, one hundred kilometers away.

It is always around venerated tombs that oaths are taken, orders given, insurrections prepared. In all of Algeria, these tombs are devotedly visited by Muslims; some of them ask the marabouts who live there for help, courage, and inspiration; others bring them offerings. On all feast days, women go in a procession to the marabouts' tombs. Dressed in white, they walk in single file, filling the air with their pathetic lamentations; when they arrive near the koubba, they surround it and sing their own kinds of litanies in a shrill, discordant voice. Then they sit down on the ground paved with varnished earthenware and, laughing and eating, tell each other about their good fortunes and amorous disappointments.

On Fridays, many Mauresques of Algiers go to the mosque of Abd-er-Rahman-elTcalbi on a plateau that dominates the sea above the Jardin Marengo, where - when I was tired of breathing the salty breeze - I entered only after removing my shoes; only with bare feet can one walk in a mosque. The women bring small objects with which to touch the tombs, and they encouraged me to also touch the tombs with something, saying it would bring me luck. In a small niche in the mosque stands a ewer filled with water. One after the other the visitors drink from this stagnant water with which the saint is believed to have quenched his thirst since the preceding Friday. Friendly Arab women have often paid me the compliment of inviting me to drink before they did.

In the Arab world, rags are a sign of mourning. In the extreme south, Negroes attach a bolus of hay to their belt when they are bereaved. In the African north, men do not go into mourning for their wives, which does not prevent them from sometimes lamenting and saying when they lose a spouse, "I have lost part of my fortune, my wife cost me one hundred duros! She made such good honey crêpes and couscous!"

When their husbands die, Muslim women are expected to show great sadness. As a sign of mourning they must abstain for four months and ten days from kohl,

90 Strong, hot, sand-laden wind from the desert. 
henna, and swak, that is, they must renounce being beautiful. They are obliged to leave their embroidered muslin and tulle dresses, their pretty sateen vests, their fine haiks, and to drape themselves in camel hair sacks and in old remnants of tent cloth. They blacken their cheeks with soot, scratch and tear their face with their nails until it bleeds, so that even though their heart is most often indifferent toward the deceased, they appear to shed red tears; their face is covered with blood as ours is flooded with tears.

When friends and relatives of a deceased shout and cry on his grave after the funeral, the tolba $^{91}$ and the marabouts harangue them with these words: "Women! Let the dead deal with Azrail (the angel of death) who weighs his good and bad actions. Your lamentations are a revolt against the will of God!"

In Algiers as well as in Constantine and Oran, Muslim mortality is higher than natality. Everywhere else there are more births than deaths: the Algerian Arab population has known a large increase in the last ten years. The Algerian climate numbs and saps people's energy. A languor of the whole being takes away the power of thinking and willing, and death enters insidiously without being recognized.

After the funeral the rich serve an immense diffa to the poor. This is quite as good as the funeral meal shared by the heirs of our dead, albeit gritting their teeth.

The Tuareg, so courageous, so brave, are terribly afraid of spirits and ghosts, so they refrain from crying for their dead for fear of seeing them resurrect. As soon as the funeral has taken place, they move their camp to put some distance between the living and the dead; they do not even give the name of the father to the son; the name dies with the man who had it. This annihilation of a dead person's memory clashes with the Arabs' cult of their great dead and is characteristic of the real differences in the customs of the Saharan nomads and the inhabitants of the Tell.

\subsection{Houris and Paradise}

Islam maintains in paradise the inequality of the sexes it has established on earth; for even though it has given legal rights to women, dead or alive, in heaven or in the desert, they are there for man's pleasure. It is known that one may not touch the Koran without first performing an ablution; but even water does not clean under certain circumstances. During menses and childbirth, a woman is forbidden to touch the Koran, even after one hundred ablutions. She takes what she wishes from the common belief; her faith is of very little concern.

"Woman has the soul of a dog," and so it is pointless for her to go to the mosque because the presence of this creature without qualities would bother men. No need then to point out that if any Muslim believer may on occasion act as a priest, women

91 Scholar; Arabic plural of taleb. 
may not act in that capacity. As you see, we are far from the times when Sheikhess Chohdah, nicknamed Women's Glory and listed among Islam's scholars, gave public lectures in the great mosque and discussed the book of the Défaites et infortunes des amants. $^{92}$

Friday is the Arabs' Sunday. But on this day devoted to God, women must weave carpets and burnouses just as on other days, and grind barley flour because the Koran condemns those who imitate Christian and Jewish infidels by abstaining from work on that day.

Liberal and anti-semitic French Catholics are in favor of a Franco-Arab alliance but not of a union, because of their prejudice of race. How much better inspired was the late great "metteur en scène" Lavigerie ${ }^{93}$ who, not content to have Arab orphans plant, at the expense of taxpayers and charitable people, thousands of hectares of vineyards on his family's land, also lifted the Negroes' spirit when he honored at Notre-Dame d'Afrique a most beautiful black Madonna, a Negro Virgin!

The mosque sees but half of the Muslim people on Fridays: men. The few women there have come to talk, not to pray. I remember them, these women squatting in an aisle, separated from the men, chatting about everything but religion. They would force me to squat with them, which hurt my legs; they counted my skirts, observed my clothes. On the other hand, it is true that they obligingly satisfied my curiosity by lifting the veils that covered their faces.

In the Sahara, there are women who pronounce oracles in the zawayas like marabouts. People come from far away to ask them to resolve disagreements, and they submit to their judgments.

All Tuareg women know how to read and write whereas, thanks to us civilizers, Algiers' Arab women languish in total ignorance.

The women who went on pilgrimage to Mecca are famous among their tribe for the rest of their lives. However, after their death, like all other Muslim women, they are entitled to only a seventy-second of a husband; in other words, a man has seventy-two houris for himself alone. Since there is not even one woman for each man now, how will Mohammed give seventy-two of them to each Muslim? Will there be a multiplication of women as there was a multiplication of bread? Probably, because according to the Koran woman was created uniquely to build an eternal harem for man and provide him with uninterrupted joys and pleasures.

"In the other world, to whom does the woman who married several men belong?"

The Prophet answers that her husbands will draw lots.

Given this divine cruelty toward them and men's custom of excluding them from their religion, Arab women are not much interested in the afterlife. Not expecting to

92 Defeats and Misfortunes of Lovers.

93 Charles Lavigerie (1825-1892), French cardinal who landed in Africa in 1868 in a time of famine; he adopted 1700 Muslim orphans, baptized them, and placed them in newly-created Christian villages. A metteur en scène is a person who directs the staging of a dramatic work. 
find happiness in heaven, the Arab woman looks for it on earth. For her the supreme felicity is to please, to inspire love; so when she complains to the cadi that she is not satisfied with her husband, he often finds in her favor saying, "I understand you because I know that women's religion is love!”

\subsection{Women Soothsayer}

While Muslim women do not believe in another life and do not make any effort to deserve it, they believe that occult influences have the power to help them enjoy this life's pleasures to the fullest. So they readily consult women soothsayers and display a true oriental credulity.

Africa is a blessed region for female magicians. Fortunetellers do not wait for clients in their apartment or their moveable home, they make house calls. They announce their presence in Algiers' streets shouting, “Guézano! Guézano!” (I tell fortunes). They usually are former loose women who escape poverty by claiming the prestigious power of knowing the future. When they hear "Guézano!” laughing Europeans appear at balconies and sometimes signal to the sibyl to come up. After numerous invocations this woman examines their hands and makes predictions which sometimes luckily come true.

These eaters of hot iron and ground glass who terrify and stupefy regular customers of cafés maures in coastal cities, juggling with horned vipers whose bite kills, are most often accompanied by young and pretty Negresses and old toothless gazanas with their tobacco-filled noses, who tell everybody their fortune. These soothsayers work together in groups of three or four; men stop them on their way and right there, in the middle of the street, the women tell them what will happen to them, poverty or riches, life or death, success or not in love! All that in a picturesque language accompanied by many gestures. Everybody laughs, the women don't mind and laugh also, then collect their due and go cheerfully on their way to find other customers.

What a difference between them and our irascible sibyls who insult the naïve lover when he admits that he does not see in the pail of water the portrait of the one who is going to love him! But the women are many and the clients are rare; so on rainy days these witches, their melhfa and haik spattered with mud, pursue a woman on her walk with their offers of service all the way to the carriage gate where she looks for shelter. They take her hand, whether she likes it or not, and seeing her alarm, they say, "Don't be afraid, you are a woman and I am a woman, put a coin in your hand and I shall tell you your past, your present, and your future."

The Arab witches not only claim to predict what will happen to each person, they are also supposed to know the properties of herbs with which they concoct beverages that can lessen or augment fertility at will, force gaiety and love, or satisfy hate. In the Sahara, men and women ask old mulatto women and tolbas who combine the functions of alchemists and magicians, to make a potion of special herbs prepared 
with frightening invocations, which they will put into the food of the one by whom they want to be loved. It is well known that burning together a male toad and a female desert snake will produce a powder that will make the person who has ingested a pinch of it do what you wish. In Algeria, fortunetellers usually carry their working tools with them: a vase with burning incense, a cane for tracing cabalistic signs, and an emerald that ensures clear vision.

Negresses heal dejected souls whose melancholia has resisted the saliva passed behind the ears, by anointing their foreheads with the warm blood of a half-dozen fatally wounded hens. In order to find enough hens for this sacrifice, they have taught the natives to enter the hen runs on all fours, their naked body coated with a hyena's fat. The dogs, terrified by the hyena's smell, do not bark: the thieves put the hens to sleep with resin smoke and carry them away in their baskets. Some soothsayers observe the movements of snakes, others the movements of clouds. The first ones read in the stars, the second ones interpret the sounds of sands and decipher what is written on rocks.

Toledo is the capital of magicians; but the marvels of the magic world are to be found in Morocco: twenty days away from Souss, near a "speaking mountain," live the most famous male and female witches in the world; the school for alchemy and necromancy they have established there attracts many students, who later visit African tribes where they are always welcome.

A soothsayer earns a very good living from Arabs, who protect their dwellings with a five fingers mark and also believe they can get rid of their diseases by making them pass into the stems of esparto grass. Travelers in the desert can frequently be seen dismounting from their horse or their camel and squatting near a tuft of esparto grass. Tying together its new shoots, they believe that they are attaching their suffering there.

Everything is supernatural for these burnoused dreamers. They are greatly impressed by artesian wells; they say, "The French, creators of pure flowing water, have discovered the key to the subterranean water hidden by the magicians.” They attribute a sometimes prodigious power to plants and animals. If touching the lion has procreative effects, the big one-meter Saharan lizards can make a woman barren and a man impotent by hitting them with its tail.

Certain African tribes keep a tiger adorned with fetishes in the depth of a sanctuary. It is offered sheep, fowl, and maize; dances are executed in its honor. Elsewhere, the crocodile is the sacred animal; to agitate a blade above the water where it resides is a capital crime. For five hundred years all of Israel prostrated itself before the bronze snake. The bear is a divinity in the north, the jaguar in Brazil, the toad in South America, the spider in islands of the Pacific.

Every year, with great pomp, an Egyptian executioner throws a magnificent doll into the Nile's devouring waters. In the past, it was a live young girl who was ritually tossed into the river to obtain a good harvest thanks to this sacrifice. 
According to Arabs, fortunetellers ${ }^{94}$ are inspired by the devil more than by God; however, these same Arabs who praise Allah claim miracles when they receive from them, in the form of amulets, small, entirely white papers which, after being carried for three days on their bare skin under the gandura or the melhfa, are transformed by ingenious formulas and appear covered with writings. O sacred chemistry! How many miracles have you authored?

\subsection{A Little Girl’s Brain}

In the Arab world, where girls are married nearly as soon as they are born, a virgin is a rarity. She is all the more prestigious: her hair and henna-painted nails are capable of holding back, suspended in the air, the rock detached from the mountain for as long as the man who carries it is in danger of being crushed under its weight. Carrying a little Moorish girl's tooth gives its owner the power to have the most ferocious animals lie down at his feet. But the part of her body that possesses the supreme quality is her brain!

The brain of a Muslim virgin not only protects from all evils, not only heals from all diseases, but gives those who are so fortunate as to possess it and wear it locked in a metal case under their turban the ability to understand all that is hidden and to be enlightened in all sciences. If Mohammed was a remarkable man, they say it is because he wore, held on his head, a young girl's brain. As you see, these good Arabs are helping M. Manouvrier ${ }^{95}$ to rehabilitate the female brain!

To obtain the magic brain there would be no hesitation to pull it out of a living child's head, but this crime is impossible because the little Arab girls, being so valuable, such a priceless commodity, are very closely watched. So in order to get a virgin's brain, graves are desecrated. A sheikh recently informed the court that the young Sahéli Halima Bent Amar, buried the day before in Mansouriah, had been unearthed during the night and her brain extracted from her cranium.

\subsection{Love as a Talisman}

Among naïve people's amulets, some are worthy of the respect of civilized people; such is the amulet made of earth shaped with tears, which is ceaselessly brought to one's lips during the absence of a loved one. When Arabs leave their home for an expedition, a war, or a long trip, they do not bid adieu to any woman of their family; it is said to bring bad luck. But their mothers, wives, and daughters, accompanied

94 In his book Respect aux droits de la femme dans l'Islamisme (Respect for Women's Rights in Islam), Mohammed Kamal calls them “masters of knavish tricks.” (author’s footnote)

95 Léonce Manouvrier (1850-1927), French anthropologist. 
by relatives and friends, furtively follow them and bathe their footprints with tears. When the men mount their horses and disappear over the horizon, those who love them bend over the road to collect the precious earth on which they walked. Amulets are then fashioned with that earth wet with tears; those who love the traveler wear them on their hearts like relics, in the belief that this token of affection will bring them back safe and sound. This love-talisman is very suggestive. We, the civilized, have not found, to prove our attachment, anything as truly touching in its simplicity.

If a man wants to be loved by an indifferent woman, he should wear an amulet written by a naked taleb with a pen carved from the wood of a male oleander and dipped in yellow ink. A famous marabout sometimes asks four or five duros to write an amulet that protects against diseases or thieves. But there are also dreadful amulets. Those containing jackal's hair make the heart cowardly; those on which one has spat three times bring death to the person wearing them.

The French often make fun of these amulets. However, are the small leather bags containing verses of the Koran, worn on the heart or attached to the neck or the arm, more ridiculous than our scapularies and our medals? 